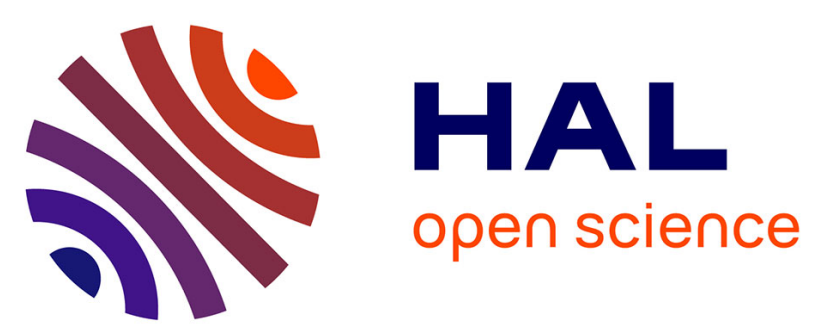

\title{
Age determination of large live trees with inner cavities: radiocarbon dating of Platland tree, a giant African baobab
}

Patrut, Karl Reden, Pelt, Diana Mayne, Daniel Lowy, Margineanu

\section{- To cite this version:}

Patrut, Karl Reden, Pelt, Diana Mayne, Daniel Lowy, et al.. Age determination of large live trees with inner cavities: radiocarbon dating of Platland tree, a giant African baobab. Annals of Forest Science, 2011, 68 (5), pp.993-1003. 10.1007/s13595-011-0107-x . hal-00930675

\section{HAL Id: hal-00930675 https://hal.science/hal-00930675}

Submitted on 1 Jan 2011

HAL is a multi-disciplinary open access archive for the deposit and dissemination of scientific research documents, whether they are published or not. The documents may come from teaching and research institutions in France or abroad, or from public or private research centers.
L'archive ouverte pluridisciplinaire HAL, est destinée au dépôt et à la diffusion de documents scientifiques de niveau recherche, publiés ou non, émanant des établissements d'enseignement et de recherche français ou étrangers, des laboratoires publics ou privés. 


\title{
Age determination of large live trees with inner cavities: radiocarbon dating of Platland tree, a giant African baobab
}

\author{
Adrian Patrut • Karl F. von Reden • Robert Van Pelt • \\ Diana H. Mayne • Daniel A. Lowy • Dragos Margineanu
}

Received: 9 October 2010 / Accepted: 23 January 2011 / Published online: 1 July 2011

(C) INRA and Springer Science+Business Media B.V. 2011

\begin{abstract}
- Introduction For large trees without a continuous sequence of growth rings in their trunk, such as the African baobab (Adansonia digitata L.), the only accurate method for age determination is radiocarbon dating. As of today, this method was limited to dating samples collected from the remains of dead specimens.

- Methods Our research extends significantly the dating of such trees to large live specimens with inner cavities. The new approach is based on collecting samples from the cavities and their subsequent radiocarbon dating.

- Results The giant two-stemmed Platland tree, also known as Sunland baobab, was investigated by using this new
\end{abstract}

Handling Editor: Erwin Dreyer

A. Patrut $(\bowtie) \cdot$ D. Margineanu

Department of Chemistry, Babes-Bolyai University,

Arany Janos 11,

400028 Cluj-Napoca, Romania

e-mail: apatrut@gmail.com

K. F. von Reden

NOSAMS Facility, Department of Geology \& Geophysics,

Woods Hole Oceanographic Institution,

Woods Hole, MA 02543, USA

R. Van Pelt

College of Forest Resources, Box 352100,

University of Washington,

Seattle, WA 98195, USA

D. H. Mayne

Baobab Trust,

Parklands 2121,

Johannesburg, South Africa

D. A. Lowy

FlexEl, LLC,

College Park, MD 20742, USA approach. AMS radiocarbon dates of the oldest sample segments originating from the two inner cavities indicate that the large stem I $\left(364.5 \mathrm{~m}^{3}\right)$ is $750 \pm 75$ years old, while the much smaller stem II $\left(136.7 \mathrm{~m}^{3}\right)$ has $1,060 \pm 75$ years. Results also show that stem I is still growing very fast, while the older stem II slowed down consistently its growth over the past 250 years. The complete mapping of Platland tree determined an overall wood volume of $501.2 \mathrm{~m}^{3}$.

- Conclusions Dating results demonstrate that the size-age relation cannot be used for estimating accurately the age of African baobabs.

Keywords Adansonia digitata $\cdot$ Radiocarbon dating $\cdot$ Age determination $\cdot$ Growth rate $\cdot$ Accelerator mass spectrometry

\section{Introduction}

For trees which exhibit annual or seasonal growth rings, ring counting, possibly refined by cross-dating, represents the most accurate and reproducible method for age and growth rate determination. Ring counting is typically performed on the remaining stumps of dead trees. Nevertheless, there are several cases in which this procedure cannot be utilized. Relevant examples are trees with growth rings that are not strictly annual or seasonal, with no welldefined rings or without a continuous sequence of rings, as a consequence of their hollow parts. In such cases, ring counting is replaced by alternative direct (radiocarbon dating) or indirect dating methods (relation size/diameterage, projections of short-term growth data, projections based on mortality rates, etc.) (Worbes 2002; Patrut et al. 2010a). The most investigated species of this type is the African baobab (Adansonia digitata L.), the angiosperm with the stoutest trunk. For large and old baobabs, a 
hypothetically accurate ring counting is not possible, as growth rings may no longer be observed in certain areas of the trunk and they are also missing in the area of large cavities.

As indirect methods often provide questionable results, radiocarbon investigation represents the only alternative method for the accurate dating of such trees. Given its higher costs, so far, radiocarbon dating was not used on the large scale. Several noteworthy investigations were performed, however, on different tropical species, for determining the age of trees and/or growth rates, for accurately dating the observed growth rings, for checking and correcting ring counting, or for providing climate information (Martinez-Ramos and Alvarez-Buylla 1998; Worbes and Junk 1999; Poussart et al. 2006). Traditionally, for large trees, such as the African baobab, this research was limited to dating wood samples collected from the remains of dead specimens, which decay very fast (Swart 1963; Patrut et al. 2007). Work reported here extends considerably the possibility of aging African baobabs, by introducing a methodology which allows, to date standing and live specimens. This new approach is based on radiocarbon dating of very small wood samples collected from the inner cavities of live baobabs. The first live specimen investigated by this methodology was the huge two-stemmed Platland tree.

Dating results for segments extracted from samples originating from the two cavities of Platland tree, which correspond to a depth of over $20 \mathrm{~cm}$ in the wood, are presented and discussed. As these segments consist of the original old wood, dating results made it possible to determine the age of the two stems of Platland tree, which was the main goal of our research. We also present for the first time results of the complete mapping of a large African baobab. The age difference of the two stems is discussed in the framework of the questionable size-age relation.

\section{Materials and methods}

\subsection{Dating live African baobabs}

The main characteristics of the new approach for age determination of large live trees via dating samples collected from their inner cavities, applied to the case of the African baobab, can be summarized as follows:

1. Collection of samples from inner cavities through cavity walls and subsequent radiocarbon dating of these samples define the new methodology.

2. The extant wood collected with an increment borer from cavities, at depth values exceeding $20 \mathrm{~cm}$, is the original old wood which corresponds to the respective positions. Such a depth is needed for excluding successive regrowth layers triggered by cavity fires and also by a somewhat limited ability of the baobab of repairing its wounds, i.e., for closing its cavity. A 60$\mathrm{cm}$ increment borer is more than sufficient for reaching the original old wood and preventing collection of any regrowth layer.

3. The age of an investigated baobab is calculated by extrapolating age values of the oldest radiocarbon-dated samples to the symmetry/geometric center of the trunk at that height. Extrapolation is done by using growth rate values of the trunk, calculated from different sample ages, as well by considering growth rate values reported in the literature.

4. The symmetry center at a certain height above ground level can be accurately determined from a cross-section of the trunk at this height.

5. In order to evaluate more accurately both the age and the growth rate dynamics, one collects additional (younger) samples from the exterior (through the bark); these samples are also radiocarbon dated.

6. Usually, the pith of a tree, including the African baobab, is not perfectly centered. However, with the exception of certain individuals with a highly irregular trunk, it is reasonable to assume that in single-stemmed baobabs, the pith is relatively close to the symmetry center of the trunk. If one assigns the symmetry center to the pith and one considers the fast growth rate of young baobabs, an additional error of \pm 50 years for the final age value would cover for all these assumptions.

7. In the case of baobabs with a multi-stemmed trunk, the current symmetry center of a stem cannot be assigned to its pith. One should consider that, after fusion, the growth of stems continued only in directions where there was room for accommodating their growth. Thus, one must calculate the symmetry center of a stem prior to fusion, which can be reasonably approximated by the pith. The moment of fusion must be estimated from the age of samples collected from the fusion area.

\subsection{The study area}

The Platland tree (Fig. 1) is located on the Sunland Nursery of the Platland farm, $10 \mathrm{~km}$ from Modjadjiskloof (formerly Duiwelskloof) and $25 \mathrm{~km}$ from Tzaneen in the Limpopo Province, South Africa. Its GPS coordinates are $23^{\circ} 37.255^{\prime}$ $\mathrm{S}, 030^{\circ} 11.884^{\prime} \mathrm{E}$, and the altitude is $719 \mathrm{~m}$. Mean annual rainfall in the area is $492 \mathrm{~mm}$ (Mooketsi station; 19252009). 


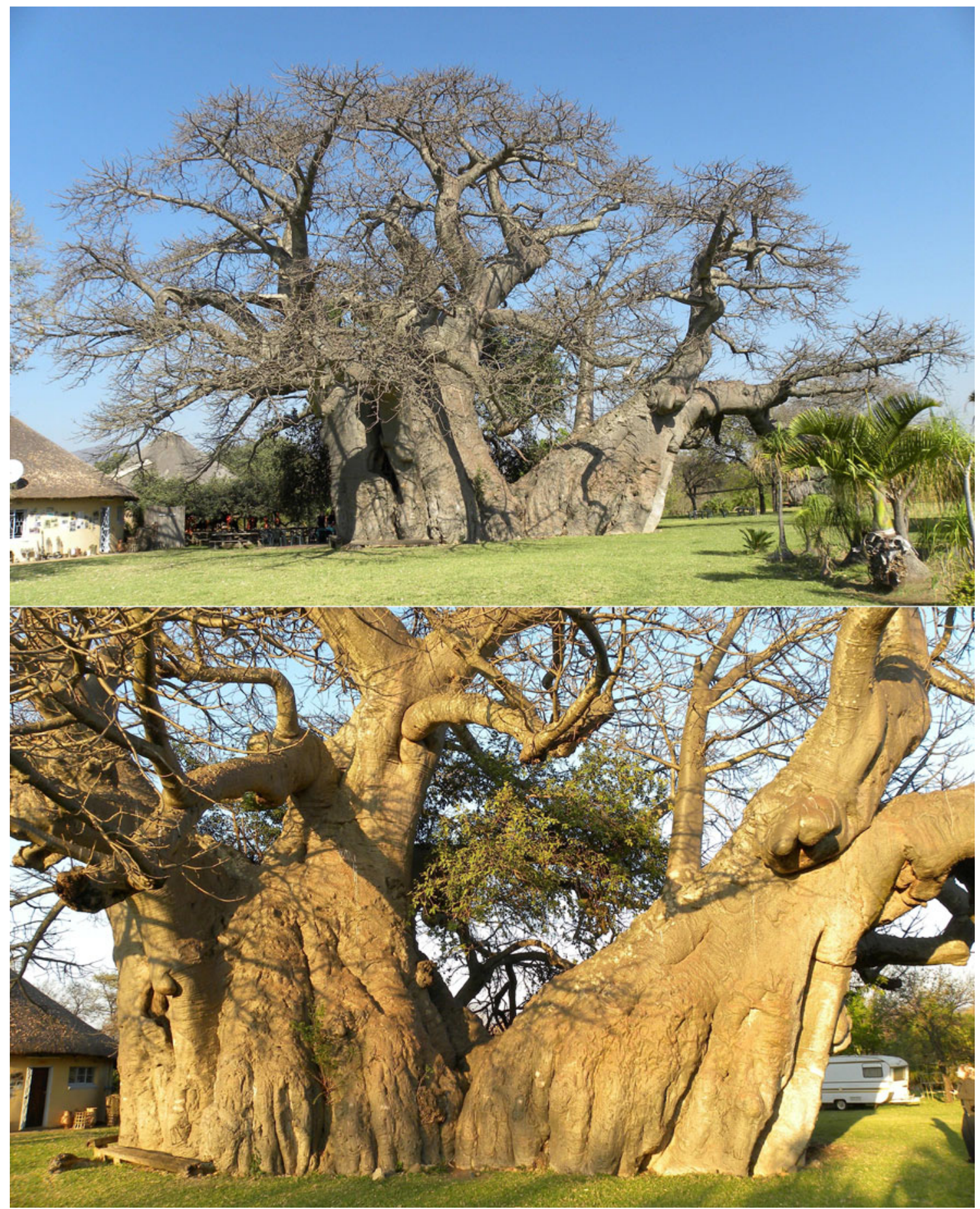

Fig. 1 (top) The very impressive Platland tree, which is also called Sunland baobab. General view taken from the east; (bottom) The image taken from the north shows the two-stemmed trunk of Platland

\subsection{Measurements}

The common external measurements of the Platland tree and the measurements inside the two inner cavities were performed by using a Bosch DLE 70 Professional laser rangefinder (Robert Bosch GmbH, Stuttgart, Germany) and graduated tapes. tree, with the larger and taller stem I to the left, while stem II is on the right. The fusion area of the stems can also be observed

Cross-sections of the Platland tree at ground level, 1, 2, 2.5, and $5 \mathrm{~m}$ were mapped by setting up a frame around the tree with a graduated tape. A compass and an Impulse 200 laser rangefinder (Laser Technology, Inc., Centennial, CO, U.S.A.) were used to map the cross-sections. Additional cross-sections on the largest section were mapped at 6.5 and $8 \mathrm{~m}$. All of the 
mostly round branch and stem sections above or around this had their basal diameters estimated by using a Criterion 400 survey laser (Laser Technology, Inc., Centennial, CO, U.S.A.). System lengths were either measured directly or interpreted from detailed photos of the tree structure without leaves. Parabolic or conic equations were used for these smaller systems based on how robust and foliated each system was.

\subsection{Sample collection}

Seven wood samples (numbered 1 to 7) were collected from different positions of the walls of the two cavities of Platland tree, according to the previously described methodology. Due to the irregular profile of the cavities' walls, the inner samples originate from heights of $0.40-1.70 \mathrm{~m}$ above cavity level. A number of three additional samples (numbered 11 to 13) were collected from the exterior of the two stems through the bark. The sampling was performed at heights of $1.20-2.75 \mathrm{~m}$ above ground level. All samples were obtained by using a Haglöf CO600 increment borer (60 cm long, $0.43 \mathrm{~cm}$ inner diameter) (Haglöf Sweden AB, Langsele, Sweden).

The projections of sampling points on a cross-section of the trunk with the cavities included are shown in Fig. 2. One should mention that all seven samples collected from the two large cavities, as well the three samples collected from the exterior, were shorter than $60 \mathrm{~cm}$, having lengths between 22 and $51 \mathrm{~cm}$. These values indicate the existence of additional hollow parts between the open cavities and the exterior of the stems. Segments with a length of $0.5 \mathrm{~cm}$ were extracted from determined positions of the original ten samples. The segments were processed and investigated by accelerator mass spectrometry (AMS) radiocarbon dating.

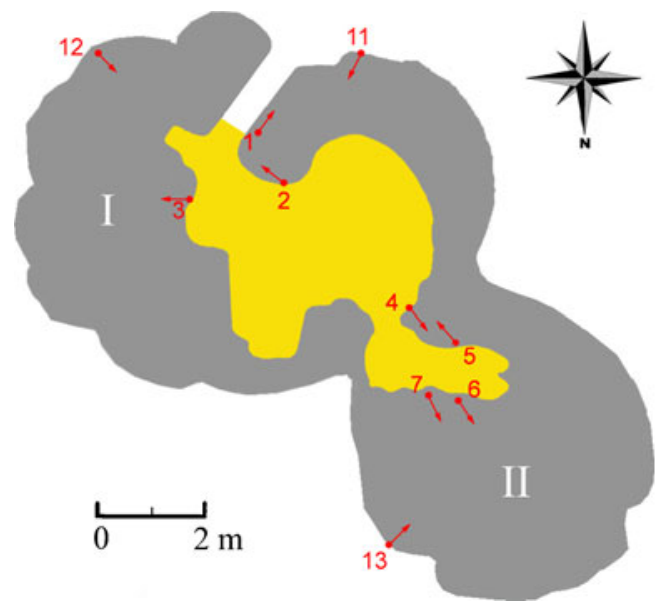

Fig. 2 Cross-section of the two-stemmed Platland tree (at $1 \mathrm{~m}$ above ground), showing the two connected cavities (displayed at cavity level), the positions of the ten sampling points and the sampling directions. Because the samples were collected at various heights, several sampling points are not located right on the contour of the cavity or of stems, which are figured at a well-defined height

\subsection{Sample/segment preparation}

The standard acid-base-acid pretreatment method (Olsson 1986) was used to remove soluble and mobile organic components. The resulting cellulose samples were combusted to $\mathrm{CO}_{2}$ by using the closed tube combustion method (Sofer 1980). Then, $\mathrm{CO}_{2}$ was reduced to graphite on iron catalyst, under hydrogen atmosphere (Vogel et al. 1984). Eventually, the resulting graphite samples were analyzed by AMS.

\subsection{AMS measurements}

Radiocarbon measurements were carried out at the National Ocean Sciences AMS Facility of the Woods Hole Oceanographic Institution with the Pelletron ${ }^{\circledR}$ Tandem $500 \mathrm{kV}$ AMS system (Roberts et al. 2010) and the Tandetron 3MV AMS system (von Reden et al. 1994). The surface of the graphite samples was sputtered with cesium ions, and the secondary negative ions were extracted and accelerated in the AMS system. ${ }^{12} \mathrm{C}$ and ${ }^{13} \mathrm{C}$ ions were measured in Faraday cups, where a ratio of their currents was recorded. Simultaneously, ${ }^{14} \mathrm{C}$ ions were recorded in a particle detector, so that instantaneous ratios of ${ }^{14} \mathrm{C}$ to ${ }^{12} \mathrm{C}$ were also recorded. These raw signals were compared to ratios obtained with a known standard material (Oxalic Acid I, NIST-SRM-4990) and converted to a fraction modern value, which was corrected for isotopic fractionation with the normalized $\delta^{13} \mathrm{C}$ value of $-25^{0} \%$. Fraction modern values were ultimately converted to a radiocarbon date.

\subsection{Calibration}

Fraction modern values were calibrated and converted into calendar ages with the OxCal v4.1 for Windows (Bronk Ramsey 2009), by using the IntCal09 atmospheric data set (Reimer et al. 2009).

\section{Results}

\subsection{Mapping results}

The trunk of Platland tree, which consists of two stems (I and II), has a total circumference at breast height (cbh; $1.30 \mathrm{~m}$ above ground level) of $34.11 \mathrm{~m}$ and a footprint of $67.9 \mathrm{~m}^{2}$, which corresponds to a functional diameter of $9.30 \mathrm{~m}$ at ground level. It is to mention that the huge trunk is covered by a very thin silver colored bark, which is less than $1 \mathrm{~mm}$ thick. The canopy dimensions are of $37.7 \mathrm{~m}$ (in direction NS) and $32.4 \mathrm{~m}$ (in direction WE).

The larger stem I has a height of $18.9 \mathrm{~m}$, a cbh value of $24.20 \mathrm{~m}$, a footprint of $43.9 \mathrm{~m}^{2}$, and a cross-sectional area 
at bh of $42.7 \mathrm{~m}^{2}$. The formal diameter at bh calculated from the cbh value in circular approximation is $7.70 \mathrm{~m}$, while the much more accurate functional dbh derived from the crosssectional area at bh is of $7.37 \mathrm{~m}$. The smaller stem II has the height of $15.8 \mathrm{~m}$, a cbh value of $18.34 \mathrm{~m}$, a footprint of $24.0 \mathrm{~m}^{2}$, and the cross-sectional area at bh of $23.3 \mathrm{~m}^{2}$. In this case, the formal dbh is $5.84 \mathrm{~m}$, while the functional dbh becomes $5.45 \mathrm{~m}$.

The two stems are connected by a fused section, which covers a shared cbh of $4.10 \mathrm{~m}$ and has a maximum height of $2.20 \mathrm{~m}$. The trunk comprises two interleading cavities on either side of the fused section, connected by a small opening/ doorway. The very large cavity inside stem I has a maximum length of $4.60 \mathrm{~m}$, a width of $4.81 \mathrm{~m}$, and a height of $4.88 \mathrm{~m}$. The irregular cavity inside stem II has a maximum length of $1.67 \mathrm{~m}$, a maximum width of $2.50 \mathrm{~m}$, and a height of $2.47 \mathrm{~m}$; it also has an elevated extension towards the north, with a length of $2.24 \mathrm{~m}$. The basal surface of cavity inside stem I is $15.9 \mathrm{~m}^{2}$, while the cavity inside stem II has the surface of $2.8 \mathrm{~m}^{2}$. There is also an elevated cavity located inside stem I, at the height of $5.80 \mathrm{~m}$. This cavity with two entrances, which is visited and used by birds as a night shelter, has the maximum dimensions of ca. $2 \times 2 \times 1.5 \mathrm{~m}$.

For hollow baobabs, the large cavities are located at ground level or, more seldom, at a certain height above ground. However, for the Platland tree, the level of cavities is at $0.78 \mathrm{~m}$ below the current ground level, suggesting that the inside level corresponds to the original ground level. The increase of the ground level over the past centuries is very probably the result of mud and sediment left behind by several flood episodes of a creek located in the close proximity of the tree. One can state that today, the trunk/base of the Platland tree is buried in the soil up to the height of $0.78 \mathrm{~m}$. After 1990, the new owners of the Platland farm opened a pub in the very large cavity inside stem I. Consequently, the tree has become heavily promoted as the Sunland "pub" baobab.

Formally, one can consider the Platland tree composed of two sections: Platland I (stem I and the corresponding branches) and Platland II (stem II and the corresponding branches). The total wood volume of the Platland tree above the present ground level was found to be $448.2 \mathrm{~m}^{3}$, i.e., $273.1 \mathrm{~m}^{3}$ below $5 \mathrm{~m}$ and $175.1 \mathrm{~m}^{3}$ over $5 \mathrm{~m}$. This total volume of $448.2 \mathrm{~m}^{3}$ above ground level consists of the volume of Platland I, which is $330.2 \mathrm{~m}^{3}$, and the volume of Platland II, which measures $118.0 \mathrm{~m}^{3}$. Nevertheless, the overall wood volume of stems and branches should be calculated above the cavities level, which is the initial ground level. Thus, the overall wood volume of the Platland tree becomes $501.2 \mathrm{~m}^{3}$, out of which $364.5 \mathrm{~m}^{3}$ for stem I and $136.7 \mathrm{~m}^{3}$ for stem II.

Cross-sections of the Platland tree at different heights are displayed in Fig. 3. The measured and calculated charac-

\section{Platland Tree}

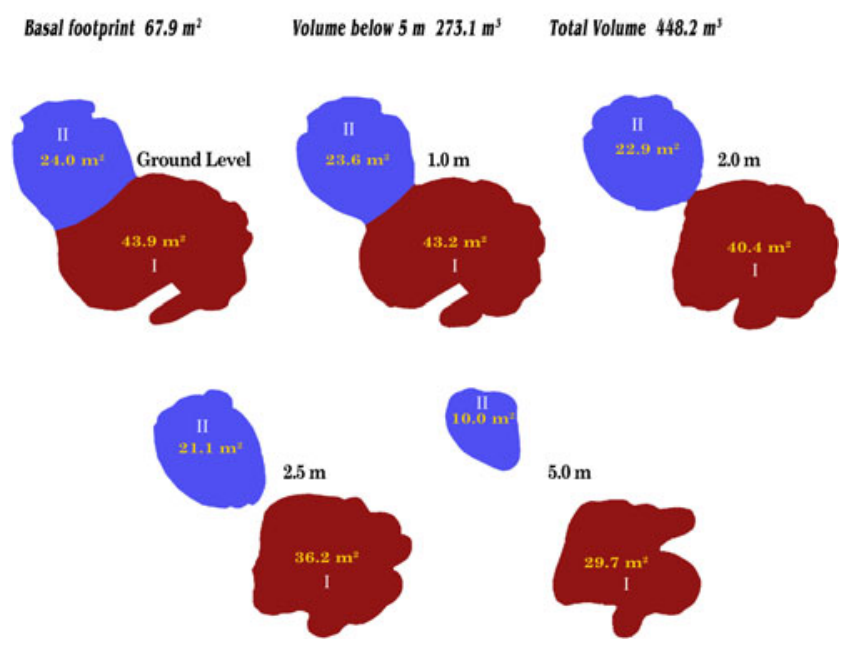

Fig. 3 Cross-sectional areas of the trunk/stems of Platland tree at different heights (ground level, $1 \mathrm{~m}, 2 \mathrm{~m}, 2.5 \mathrm{~m}$, and $5 \mathrm{~m}$ )

teristic parameters of the Platland tree are summarized in Table 1.

\subsection{AMS results and calibrated ages}

Fraction modern values and radiocarbon dates of the oldest segment of each of the 10 samples collected from the cavities and from the exterior, which were labeled by the sample code/number followed by the additional index $x$, are listed in Tables 2 and 3. Radiocarbon dates and errors were rounded to the nearest year.

For calibration, we used the general IntCal09 data set (Reimer et al. 2009), rather than the SHCal04 data set for the Southern Hemisphere (McCormack et al. 2004). Our choice is justified by the fact that the SHCal04 curve does not yet contain information for lower southern latitudes and does not include results from Africa for the time frame corresponding to our sample ages. The offset between calibrated ages obtained when using the two calibration data sets is of several decades.

Calibrated (cal) ages are also displayed in Tables 2 and 3. The 1- $\sigma$ probability distribution was chosen to derive calibrated age ranges. For three segments $(1 x, 3 x, 7 x)$, the $1-\sigma$ distribution is consistent with only one range of calendar years (marked in italics), while for the other seven segments $(2 x, 4 x, 5 x, 6 x, 11 x, 12 x, 13 x)$, the $1-\sigma$ distribution corresponds to several ranges of calendar years. For these segments, the confidence interval of one range (marked in italics) is much greater than of the others; therefore, it was selected as the cal $\mathrm{AD}$ range of the segment for the purpose of this discussion. 
Table 1 Measured and calculated main parameters of the Platland tree

\begin{tabular}{|c|c|c|c|}
\hline Parameter (unit) & Platland tree & Platland I & Platland II \\
\hline Height (m) & 18.9 & 18.9 & 15.8 \\
\hline Circumference at bh (m) & 34.11 & 24.20 & 18.34 \\
\hline Formal diameter at bh $(\mathrm{m})$ & 10.86 & 7.70 & 5.84 \\
\hline Footprint $\left(\mathrm{m}^{2}\right)$ & 67.9 & 43.9 & 24.0 \\
\hline Basal functional diameter $(\mathrm{m})$ & 9.30 & 7.48 & 5.43 \\
\hline Cross-sectional area at $1 \mathrm{~m}\left(\mathrm{~m}^{2}\right)$ & 66.8 & 43.2 & 23.6 \\
\hline Cross-sectional area at bh (m) & 66.0 & 42.7 & 23.3 \\
\hline Functional diameter at bh (m) & 9.17 & 7.37 & 5.45 \\
\hline Cross-sectional area at $2 \mathrm{~m}\left(\mathrm{~m}^{2}\right)$ & 63.2 & 40.4 & 22.9 \\
\hline Cross-sectional area at $2.5 \mathrm{~m}\left(\mathrm{~m}^{2}\right)$ & 57.3 & 36.2 & 21.1 \\
\hline Cross-sectional area at $5 \mathrm{~m}\left(\mathrm{~m}^{2}\right)$ & 39.7 & 29.7 & 10.0 \\
\hline Wood volume below $5 \mathrm{~m}\left(\mathrm{~m}^{3}\right)$ & 273.1 & 186.8 & 86.3 \\
\hline Wood volume over $5 \mathrm{~m}\left(\mathrm{~m}^{3}\right)$ & 175.1 & 143.4 & 31.7 \\
\hline Total wood volume above ground level $\left(\mathrm{m}^{3}\right)$ & 448.2 & 330.2 & 118.0 \\
\hline Overall wood volume above cavities level $\left(\mathrm{m}^{3}\right)$ & 501.2 & 364.5 & 136.7 \\
\hline Cavity/cavities area $\left(\mathrm{m}^{2}\right)$ & 18.7 & 15.9 & 2.8 \\
\hline
\end{tabular}

For obtaining single calendar age values of segments, we derived a mean calendar age of each segment from the 1- $\sigma$ range with the highest probability. Calendar ages of segments represent the difference between $\mathrm{AD} 2010$ and the mean value of the selected 1- $\sigma$ range, with the corresponding error. Calendar ages and errors were rounded to the nearest 5 years.

Table 2 AMS radiocarbon dating results and calibrated calendar ages of the oldest segments of samples collected from the cavities

\begin{tabular}{|c|c|c|c|c|c|}
\hline $\begin{array}{l}\text { Segment code } \\
\text { [stem] }\end{array}$ & $\begin{array}{l}\text { Depth }^{\mathrm{a}}\left[\text { height }^{\mathrm{b}}\right] \\
\left(10^{-2} \mathrm{~m}\right)\end{array}$ & $\begin{array}{l}\text { Fraction modern } \\
\text { [error] }\end{array}$ & $\begin{array}{l}\text { Radiocarbon date } \\
\text { [error] } \\
\left({ }^{14} \mathrm{C} \text { years } \mathrm{BP}\right)\end{array}$ & $\begin{array}{l}\mathrm{Cal} \mathrm{AD} \text { range(s) } \\
1-\sigma \\
{[\text { confidence interval] }}\end{array}$ & $\begin{array}{l}\text { Segment age } \\
\text { [error] } \\
\text { (calendar years) }\end{array}$ \\
\hline $1 x[\mathrm{I}]$ & $23[148]$ & $0.9401[ \pm 0.0034]$ & $496[ \pm 27]$ & $1415-1438$ [68.2\%] & $585[ \pm 10]$ \\
\hline $2 x[\mathrm{I}]$ & $21[145]$ & $0.9316[ \pm 0.0036]$ & $569[ \pm 29]$ & $\begin{array}{l}1320-1350[39.8 \%] \\
1391-1412[28.4 \%]\end{array}$ & $675[ \pm 15]$ \\
\hline $3 x[\mathrm{I}]$ & $25[90]$ & $0.9501[ \pm 0.0034]$ & $411[ \pm 27]$ & $1441-1485[68.2 \%]$ & $545[ \pm 20]$ \\
\hline $4 x[\mathrm{I}]$ & $48[50]$ & $0.9601[ \pm 0.0022]$ & $327[ \pm 18]$ & $\begin{array}{l}1515-1529[10.4 \%] \\
1542-1599[44.8 \%] \\
1618-1634[13.0 \%]\end{array}$ & $440[ \pm 20]$ \\
\hline $5 x[\mathrm{II}]$ & 45 [102] & $0.9597[ \pm 0.0033]$ & $330[ \pm 27]$ & $\begin{array}{l}1495-1529[18.2 \%] \\
1541-1602[38.2 \%] \\
1616-1634[11.8 \%]\end{array}$ & $440[ \pm 30]$ \\
\hline $6 x[\mathrm{II}]$ & $21[170]$ & $0.8930[ \pm 0.0029]$ & $909[ \pm 23]$ & $\begin{array}{l}1045-1095[39.6 \%] \\
1120-1142[16.0 \%] \\
1147-1164[12.6 \%]\end{array}$ & $940[ \pm 25]$ \\
\hline $7 x[\mathrm{III}]$ & $23[40]$ & $0.9003[ \pm 0.0030]$ & $845[ \pm 24]$ & $1168-1221[68.2 \%]$ & $815[ \pm 25]$ \\
\hline
\end{tabular}

${ }^{a}$ Depth in the wood of the oldest dated segment (from the cavity wall)

${ }^{\mathrm{b}}$ Height above cavity level (which is $0.78 \mathrm{~m}$ below ground level) 
Table 3 AMS radiocarbon dating results and calibrated calendar ages of the oldest segments of samples collected from the exterior

\begin{tabular}{|c|c|c|c|c|c|}
\hline $\begin{array}{l}\text { Segment code } \\
\text { [stem] }\end{array}$ & $\begin{array}{l}\text { Depth }^{\mathrm{a}}\left[\text { height }^{\mathrm{b}}\right] \\
\left(10^{-2} \mathrm{~m}\right)\end{array}$ & $\begin{array}{l}\text { Fraction modern } \\
\text { [error] }\end{array}$ & $\begin{array}{l}\text { Radiocarbon date } \\
\text { [error] } \\
\left({ }^{14} \mathrm{C} \text { years } \mathrm{BP}\right)\end{array}$ & $\begin{array}{l}\text { Cal AD range(s) } \\
1-\sigma \\
{[\text { confidence interval] }}\end{array}$ & $\begin{array}{l}\text { Segment age } \\
\text { [error] } \\
\text { (calendar years) }\end{array}$ \\
\hline $11 x[\mathrm{I}]$ & 45 [134] & $0.9939[ \pm 0.0034]$ & $49[ \pm 27]$ & $\begin{array}{l}1706-1720[12.1 \%] \\
1819-1833[10.4 \%] \\
1862-1915[45.7 \%]\end{array}$ & $120[ \pm 25]$ \\
\hline $12 x[\mathrm{I}]$ & $51[275]$ & $0.9849[ \pm 0.0031]$ & $122[ \pm 25]$ & $\begin{array}{l}1685-1707[12.1 \%] \\
1719-1732[7.1 \%] \\
1808-1826[9.2 \%] \\
1833-1885[31.5 \%] \\
1913-1928[8.2 \%]\end{array}$ & $150[ \pm 25]$ \\
\hline $13 x[\mathrm{II}]$ & $20[120]$ & $0.9791[ \pm 0.0028]$ & $170[ \pm 22]$ & $\begin{array}{l}1669-1682[11.6 \%] \\
1736-1781[40.1 \%] \\
1799-1805[5.5 \%] \\
1931-1945[11.0 \%]\end{array}$ & $250[ \pm 25]$ \\
\hline
\end{tabular}

${ }^{\mathrm{a}}$ Depth in the wood of the oldest dated segment (from the bark)

${ }^{\mathrm{b}}$ Height above ground level

\subsection{Dating results of samples collected from the cavities}

The segments of samples collected from the cavities of Platland tree, which correspond to a depth in the wood up to $15-20 \mathrm{~cm}$, consisted exclusively of new growth layers triggered by successive fires. The dating results revealed six major fire events that affected the cavities of the Platland tree, which were dated around $\mathrm{AD} 1550,1650,1780,1900,1955$, and 1990 (as established by using the general IntCal04 or IntCal09 calibration); however, this investigation did not enable to determine the age of the two stems (Patrut et al. 2010a).

Here, we present dating results of the oldest segment of each of the seven cavity samples, labeled by an additional index $x$. For a given sample, the oldest segment corresponds to depths in the wood from 21 to $48 \mathrm{~cm}$. The AMS results and calibrated ages are listed in Table 2. The results are in good agreement with the original positions of the respective segments/samples in the two stems, showing that these segments consist of the original old wood. The sequence of segment ages demonstrates that the trunk of Platland tree comprises two stems which fused partially some time ago.

The radiocarbon date of the oldest segment $2 x$ originating from the cavity inside stem I was of $569 \pm 29$ BP (before present, i.e., before $\mathrm{AD}$ 1950), which corresponds to a calibrated age of $675 \pm 15$ years. However, the oldest dated segment $6 x$ originates from the cavity inside stem II; its radiocarbon date was of $909 \pm 23$ BP, corresponding to a calibrated age of $940 \pm 25$ years.

The radiocarbon dates of the deepest segments collected from the two cavities toward the fusion/common area, i.e.,
$4 x$ and $5 x$, were $327 \pm 18$ and $330 \pm 27$ BP, respectively. These values correspond to calibrated ages of $440 \pm 20$ and $440 \pm$ 30 years. The practically identical values indicate that the two stems of Platland tree fused partially at least 440 years ago. Consequently, one can consider that the stems of Platland tree fused ca. 450 years ago, around AD 1560.

\subsection{Dating results of samples collected from the exterior}

The dating results and calibrated ages of the deepest and oldest segments of the three samples collected from the exterior of stems are shown in Table 3. The two deepest segments (45 and $51 \mathrm{~cm}$ ) originating from stem I, i.e., $11 x$ and $12 x$, at different heights above ground (1.34 and $2.75 \mathrm{~m}$ ), were radiocarbon dated to $49 \pm 27$ and $122 \pm 25$ BP. The corresponding calibrated ages are $120 \pm 25$ and $150 \pm$ 25 years.

The deepest segment $13 x(20 \mathrm{~cm})$ originating from stem II, at a height of $1.20 \mathrm{~m}$ above ground, had a radiocarbon date of $170 \pm 22$ BP, with a corresponding calibrated age of $250 \pm 25$ years.

\subsection{Growth rates of the stems}

Calibrated ages and positions of segments $11 x$ and $12 x$, which originate from samples collected from the exterior of stem I, were used to derive the mean radial increase. Thus, stem I had grown by $3.75 \times 10^{-3} \mathrm{~m}_{\text {year }}{ }^{-1}$ over the past ca. 120 years to the height of $1.34 \mathrm{~m}$, and by $3.40 \times$ $10^{-3} \mathrm{~m}$ year ${ }^{-1}$ over the past ca. 150 years to the height of 
$2.75 \mathrm{~m}$. Such high values indicate that the very large stem I is still growing very fast.

However, as reported elsewhere (Patrut et al. 2010b), the mean radial increase expresses only an apparent growth rate of trunk/stems. Trees grow in three dimensions and their size is accurately expressed by the wood volume of the trunk/ stems, which is in proportion to the cross-sectional areas at different heights. Consequently, the area increase and volume increase are much better estimates of the growth rate than the radial increase. If one considers in this respect the dating results and positions of all six samples/segments collected from the cavity and the exterior of stem I, one can state that stem I accelerated its growth over the past ca. 150 years. This result corresponds to our previous research on African baobabs (Patrut et al. 2010b), as well to other research done on giant tree species (Sillett et al. 2010).

The calibrated age and position of segment $13 x$, which originates from the sample collected from the exterior of stem II, shows that this stem had grown by only $0.80 \times$ $10^{-3} \mathrm{~m}$ year ${ }^{-1}$ over the past ca. 250 years to the height of $1.20 \mathrm{~m}$. This low value demonstrates that the smaller and older stem II slowed down its growth considerably and that it could be close to the final stage of the African baobab's life cycle, when trees almost stop growing.

\subsection{Ages of the stems}

The oldest segments $2 x$ and $6 x$ from the cavities inside stem I and stem II consist of the original old wood, which corresponds to the respective positions in the stems. The extrapolation of their calibrated ages to the presumptive center/pith of each stem enabled us for determining the ages of the two stems of Platland tree.

The segments $2 x$ and $6 x$ originate from heights of 1.45 and $1.70 \mathrm{~m}$ above cavity level, corresponding to values of 0.67 and $0.92 \mathrm{~m}$ above ground. For extrapolation, we used field measurements, as well a cross-section of the two stems at $1 \mathrm{~m}$, which is close to the segment heights (see Fig. 4).

The cross-sections at ground level and at $1 \mathrm{~m}$ show that both stems of the Platland tree have relatively symmetrical transversal sections, with quasi-ellipsoidal shapes. In this case, for determining the presumptive center/pith of each stem, i.e., the symmetry center, it is sufficient using the axes which touch the center of the fusion section.

Age of stem I In the cross-section of stem I, we displayed the minor axis of the ellipse, from an external point $Y$ to the fusion point $\mathrm{O}$, which is the conjugate diameter from $\mathrm{SE}$ to $\mathrm{NW}$. Its length is $\mathrm{YO}=7.40 \mathrm{~m}$. The present center of stem I can be approximated with the midpoint of the axis YO, denoted as $\mathrm{C}_{\mathrm{I}}$. In this case, the two minor semi-axes/minor radii are $\mathrm{YC}_{\mathrm{I}}=\mathrm{C}_{\mathrm{I}} \mathrm{O}=3.70 \mathrm{~m}$.

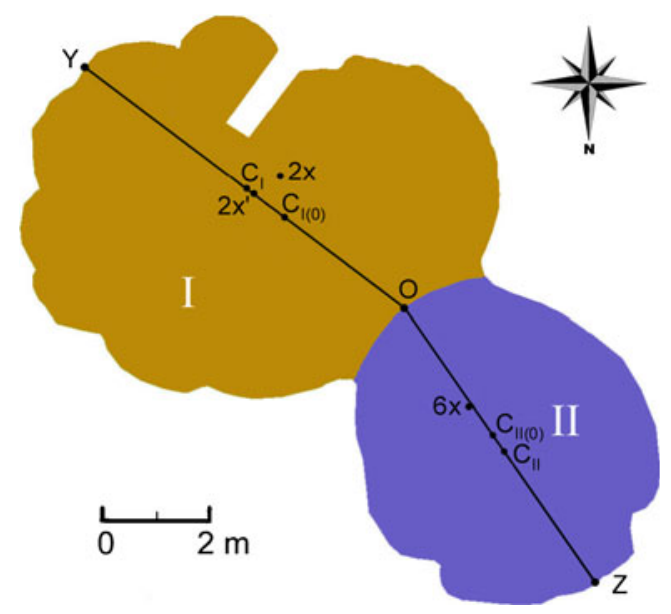

Fig. 4 Cross-section of the two stems (at $1 \mathrm{~m}$ above ground) showing the accurate positions of the oldest dated segments from each cavity $(2 x, 6 x)$, along with the present center $\left(\mathrm{C}_{\mathrm{I}}, \mathrm{C}_{\mathrm{II}}\right)$ and the original center $\left(\mathrm{C}_{\mathrm{I}(\mathrm{o})}, \mathrm{C}_{\mathrm{II}(\mathrm{o})}\right)$ of each stem

It is mandatory, however, to determine the presumptive position of the original center/pith of stem I, labeled $\mathrm{C}_{\mathrm{I}(\mathrm{o})}$, which can be approximated by the midpoint of the conjugate diameter at the fusion moment, that occurred ca. 450 years ago. After fusion, stem I had no more room for growing in direction NW. Therefore, the original center $\mathrm{C}_{\mathrm{I}(\mathrm{o})}$ is shifted toward NW relative to the present center $\mathrm{C}_{\mathrm{I}}$. Therefore, we calculated the linear increase in radius of stem I over the past 450 years, in direction SE. The age of segment $11 x$ indicates that stem I had grown toward SE by $0.45 \mathrm{~m}$ over the past ca. 120 years. In a very conservative estimate, if we consider that this relatively large mean radial increase was constant over the past 450 years, the radial increase toward SE over this period was of ca. $1.70 \mathrm{~m}$. In this case, the corresponding axis/diameter of stem I was of $7.40-1.70=5.70 \mathrm{~m}$ at the fusion time, with the two semi-axis/radii, including $\mathrm{C}_{\mathrm{I}(\mathrm{o})}-\mathrm{O}$, of $2.85 \mathrm{~m}$. Thus, the distance between the present center $\mathrm{C}_{\mathrm{I}}$ and the original center $\mathrm{C}_{\mathrm{I}(\mathrm{o})}$ becomes $\mathrm{C}_{\mathrm{I}}-\mathrm{C}_{\mathrm{I}(\mathrm{o})}=0.85 \mathrm{~m}$. The point $2 x$, which represents the intercept with the YO axis of the virtual annual ring corresponding to the position of segment $2 x$, is located at $3.75 \mathrm{~m}$ from the external point $\mathrm{Y}$ and at $0.80 \mathrm{~m}$ from the original center $\mathrm{C}_{\mathrm{I}(\mathrm{o})}$, i.e., $\mathrm{Y}-2 x=3.75 \mathrm{~m}$ and $2 x-\mathrm{C}_{\mathrm{I}(\mathrm{o})}=0.80 \mathrm{~m}$.

In order to determine the age of stem I, one should add to the age of the oldest segment $2 x(675 \pm 25$ years) the time needed by stem I for growing from 0 to a radius of $0.80 \mathrm{~m}$. The growth rate of African baobabs, especially during their early life stage, is very different. However, if we consider that the stem I of Platland tree had grown fast and it is still fast growing, then, based on its current dimensions, sample ages and also our previous research (Patrut et al. 2010b), one can estimate that the time needed to stem I for reaching a radius of $0.80 \mathrm{~m}$ was of ca. 75 years. All these approximations sum to a maximum 
error of \pm 75 years for the final age of stem I, including the age error of segment $2 x$. Hence, the calculated final age of stem I is $750 \pm 75$ years. One can state that it started growing around $\mathrm{AD} 1260$.

Age of stem II In this case, we showed in the cross-section of stem II the major axis of the ellipse, from an external point $\mathrm{Z}$ to the fusion point $\mathrm{O}$. This is also the transverse diameter from $\mathrm{NW}$ to $\mathrm{SE}$, with a length $\mathrm{ZO}=6.44 \mathrm{~m}$. The present center of stem II can be approximated by the midpoint of the axis $\mathrm{ZO}$, marked as $\mathrm{C}_{\mathrm{II}}$. The two major semi-axes/major radii are $\mathrm{ZC}_{\mathrm{II}}=\mathrm{C}_{\mathrm{II}} \mathrm{O}=3.22 \mathrm{~m}$.

The original center/pith of stem II, labeled $\mathrm{C}_{\mathrm{II}(\mathrm{o})}$, can be approximated by the midpoint of the transverse diameter at the fusion moment. After fusion, stem II had no more room for growing in direction SE. Consequently, the original center $\mathrm{C}_{\mathrm{II}(\mathrm{o})}$ is shifted toward $\mathrm{SE}$ relative to the present center $\mathrm{C}_{\mathrm{II}}$. For calculating the increase in radius of stem II over the past 450 years toward NW, we used the age of sample $13 x$, which indicates a growth of $0.20 \mathrm{~m}$ over the past 250 years. As stated, this low value indicates that the growth of stem II slowed down considerably over this time frame. If one considers that the mean radial increase was around twice faster from the fusion moment up to 250 years ago, the linear increase toward NW over the past 450 years was of ca. $0.52 \mathrm{~m}$. Thus, the corresponding axis/diameter of stem II was of $6.44-0.52=5.92 \mathrm{~m}$ at the fusion time, with the two semi-axis/radii, including $\mathrm{C}_{\mathrm{II}(\mathrm{o})}-\mathrm{O}$ of $2.96 \mathrm{~m}$. The distance between the present center $\mathrm{C}_{\mathrm{II}}$ and the original center $\mathrm{C}_{\mathrm{II}(\mathrm{o})}$ becomes $\mathrm{C}_{\mathrm{II}}-\mathrm{C}_{\mathrm{II}(\mathrm{o})}=0.26 \mathrm{~m}$. The segment $6 x$ was practically positioned on the axis $\mathrm{ZO}$, at $2.02 \mathrm{~m}$ from the fusion point $\mathrm{O}$ and at $0.94 \mathrm{~m}$ from the original center $\mathrm{C}_{\mathrm{II}(\mathrm{o})}$, i.e., $\mathrm{O}-6 x=2.02 \mathrm{~m}$ and $6 x-\mathrm{C}_{\mathrm{II}(\mathrm{o})}=0.94 \mathrm{~m}$.

For determining the age of the stem II, one should add to the age of the oldest segment $6 x$ ( $940 \pm 25$ years) the time needed to stem II for growing from 0 to a radius of $0.94 \mathrm{~m}$. If we consider that the stem II of Platland tree has grown much slower than stem I, its smaller dimensions, the older sample ages and also our previous research, we can estimate that the time needed to stem II for reaching a radius of $0.94 \mathrm{~m}$ was of ca. 120 years. All approximations are within the final error of \pm 75 years. The calculated final age of stem II becomes 1,060 75 years, indicating that it started growing around AD 950 .

\section{Discussion}

\subsection{The size of Platland tree}

The Platland tree is listed in the South African National Register of Big Trees and is included in the South African
List of Champion Trees (Esterhuyse et al. 2001; Department of Water Affairs and Forestry 2008). The only accurate parameter of the true size of a tree is the wood volume. The overall wood volume of Platland tree $\left(501.2 \mathrm{~m}^{3}\right)$ is considerably larger than that of the Sagole tree $\left(414.1 \mathrm{~m}^{3}\right)$, which is generally considered to be the biggest baobab (Van Pelt, unpublished results). Therefore, according to the volume values reported here, the Platland tree becomes the largest known African baobab.

\subsection{The relation size-age in the case of Platland tree's stems}

Commonly, one considers that the life span/longevity of a tree specimen, in our case of an African baobab, depends on several factors: (1) its genetic potential; (2) the environment (including mean annual rainfall, altitude, mean annual temperature, number of rainy seasons per year, number of frosty days per year, nature of the soil, slope of the land, availability to underground water sources, etc.); (3) the number and severity of dangerous events and disease episodes during its life cycle (fire episodes, fungi attack, insects, baobab disease, elephant damage, human damage, drought periods, flood, frost episodes, etc.).

Theoretically, individuals having all these factors identical should grow over time at the same rate. Consequently, under identical conditions, the biggest/largest trees may also be the oldest. Such considerations justify the common fallacy about trees that size is in direct proportion to their age. Certain baobab researchers noted, however, considerable size differences between individuals of identical age, which were attributed to site differences. Moreover, important size differences between specimens growing on the same site were reported; these dissimilarities were considered to be mainly of genetic origin (Breitenbach 1985; Wickens and Lowe 2008).

Our study on the Platland tree demonstrates, once again, how questionable the size-age relation is and the large errors it can generate. According to complete measurements and dating results, the very large stem I is considerably younger than the smaller stem II (overall wood volume 364.5 vs. $136.7 \mathrm{~m}^{3}$; age 750 vs. 1,060 years). A preliminary genetic research (Catana and Patrut, unpublished results) suggested that the two stems of Platland tree possess identical DNA and belong to a single individual. The two stems have also grown on the same site. In this case, we need an explanation for the unexpected finding that a stem which is almost three times bigger is, however, over 300 years younger than the smaller stem of the same tree.

Researchers of tall and large tree species around the world learned from their field experience that the largest specimens are usually not also the oldest. Typically, the largest specimens are those which had grown very fast when they were young and, eventually, continued their 
rapid growth (Hartesveldt et al. 1975). The research reported here demonstrates that such statements might be also valid for the African baobab. Our research on radiocarbon dating of baobabs (Patrut et al. 2010c), as well dating results presented by other researchers (Swart 1963; Woodborne et al. 2010) show that very large specimens are not necessarily among the oldest trees and that mediumsized individuals can also be very old. If one considers that the largest baobabs are those which grew very fast over their first ca. 100 years of life and maintained their rapid growth, we may have an explanation for our results on the two stems of Platland tree. In this case, stem I had probably grown much faster and is also considerably bigger, as the climate conditions in the area over its first century of life (ca. AD 1260-1360) were probably much more favorable for baobabs than over the first century of stem II (ca. AD 950-1050).

\subsection{The Platland tree system}

According to dating results, the present trunk of the Platland tree comprises two stems of different ages. Therefore, morphologically, it can be considered a double tree. On the other hand, according to the preliminary genetic analysis, the Platland tree is a single individual. Both stems sprouted very probably from the same rootstock at different times and, therefore, they have identical DNA.

However, in the case of multi-stemmed and multigeneration baobabs, such as the Platland tree, it is a difficult to state whether they are single or multiple trees. They should be rather considered "tree systems", with a complex development over a long life cycle. Over time, stems might die and collapse, while new stems can sprout at any moment from the roots or from the other broken or unbroken stems.

Based on the dating results, stem II of Platland tree had grown over 300 years without being disturbed by the presence of another stem. Nevertheless, it has an important lean toward NW (up to $40^{\circ}$ ) and the cross-sections show an obvious miss in its ellipsoidal shape in the present fusion area. These aspects suggest that stem II could have been pushed constantly toward NW after it started growing, possibly by a larger and older stem 0 , located approximately on the site of stem I. In this hypothetical scenario, stem 0 died and collapsed at a certain moment and was "replaced" by the present stem I, which might have emerged from its remains. However, it is improbable that stem I would still comprise somewhere old wood traces originating from stem 0 . If this scenario had happened, then the multi-stemmed and multi-generation Platland tree system should be much older than the age we derived from radiocarbon dating.
Acknowledgements This work was fully funded by the Romanian Authority CNCSIS-UEFISCDI under grant PN II-IDEI 2354, Nr. 1092. AMS radiocarbon dating at the NOSAMS Facility is supported by the U.S. National Science Foundation under Cooperative Agreement OCE-0753487. We would like to thank Heather and Doug van Heerden, the owners of Sunland Nursery, for granting permission for on-site investigation and also for sampling the Platland tree.

\section{References}

Bronk Ramsey C (2009) Bayesian analysis of radiocarbon dates. Radiocarbon 51:337-360

von Breitenbach F (1985) Aantekeninge oor die groeitempo van aangeplante kremeteartbome (Adansonia digitata) en opmerkinge ten opsigte van lewenstyd, groeifases en genetiese variasie van die spesie. J Dendrology 5:1-21

Department of Water Affairs and Forestry (South Africa) (2008) List of champion trees. Available at http://www2.dwaf.gov.za

Esterhuyse N, von Breitenbach J, Sőhnge H (2001) Remarkable trees of South Africa. Briza, Pretoria, pp 155-161

Hartesveldt RJ, Harvey HT, Shellhammer HS (1975) The giant sequoias of the Sierra Nevada. National Park Service, Washington, pp 57-59

Martínez-Ramos M, Alvarez-Buylla ER (1998) How old are tropical rain forest trees? Trends in Plant Science 3:400-405

McCormack FG, Hogg AG, Blackwell PG, Buck CE, Higham TFG, Reimer PJ (2004) SHCa104 Southern Hemisphere calibration, 011.0 cal kyr BP. Radiocarbon 46:1087-1092

Olsson IU (1986) Radiometric Methods. In: Berglund B (ed) Handbook of Holocene palaeoecolgy and palaeohydrology. Wiley, Chichester, pp 273-312

Patrut A, von Reden K, Lowy DA, Alberts AH, Pohlman JW, Wittmann R, Gerlach D, Xu L, Mitchell CS (2007) Radiocarbon dating of a very large African baobab. Tree Physiol 27:1569-1574

Patrut A, Mayne DH, von Reden KF, Lowy DA, Van Pelt R, McNichol AP, Roberts ML, Margineanu D (2010a) Fire history of a giant African baobab evidenced by radiocarbon dating. Radiocarbon 52:717-726

Patrut A, Mayne DH, von Reden KF, Lowy DA, Venter S, McNichol AP, Roberts ML, Margineanu D (2010b) Age and growth rate dynamics of an old African baobab determined by radiocarbon dating. Radiocarbon 52:727-734

Patrut A, von Reden KF, Lowy DA, Mayne DH, Elder KE, Roberts ML, McNichol AP (2010c) Comparative AMS radiocarbon dating of pretreated versus non-pretreated tropical wood samples. Nucl Instr Methods B 268:910-913

Poussart PM, Mynemi SCB, Lanzirotti A (2006) Tropical dendrochemistry: a novel approach to estimate age and growth from ringless trees. Geophys Res Lett 33:L17711

Reimer PJ, Baillie MGL, Bard E, Bayliss A, Beck JW, Blackwell PG, Bronk RC, Buck CE, Burr GS, Edwards RL, Friedrich M, Grootes PM, Guilderson TP, Hajdas I, Heaton TJ, Hogg AG, Hughen KA, Kaiser KF, Kromer B, McCormac FG, Manning SW, Reimer RW, Richards DA, Southon JR, Talamo S, Turney CSM, van der Plicht J, Weyhenmeyer CE (2009) IntCal09 and Marine09 radiocarbon age calibration curves, 0-50,000 years cal B. Radiocarbon 51:1111-1150

Roberts ML, Burton JR, Elder KL, Longworth BE, McIntyre CP, von Reden KF, Han BX, Rosenheim BE, Jenkins WJ, Galutschek E, McNichol AP (2010) A high-performance ${ }^{14} \mathrm{C}$ accelerator mass spectrometry system. Radiocarbon 52:228-235

Sillett SC, Van Pelt R, Koch GW, Ambrose AR, Carroll AL, Antoine ME, Mifsud BF (2010) Increasing wood production through old age in tall trees. For Ecol Manag 259:976-994 
Sofer Z (1980) Preparation of carbon dioxide for stable carbon isotope analysis of petroleum fractions. Anal Chem 52:1389-1391

Swart ER (1963) Age of the baobab tree. Nature 198:708-709

Vogel JS, Southon JR, Nelson DE, Brown TA (1984) Performance of catalytically condensed carbon for use in accelerator mass spectrometry. Nucl Instr Methods B 5:289-293

von Reden KF, Schneider RJ, Cohen GJ, Jones GA (1994) Performance characteristics of the $3 \mathrm{MV}$ Tandetron AMS system at the National Ocean Sciences AMS Facility. Nucl Instr Methods B 92:7-11
Wickens GE, Lowe P (2008) The baobabs: pachycauls of Africa, Madagascar and Australia. Springer, Dordrecht, pp 141-142

Woodborne S, Hall G, Basson S, Zambatis G, Zambatis N (2010) The death of a giant: on the age of baobabs. Savanna Network Meeting, Skukuza

Worbes M, Junk WJ (1999) How old are tropical trees? The persistence of a myth. IAWA J 20:255-260

Worbes M (2002) One hundred years of tree-ring research in the tropics: a brief history and an outlook to future challenges. Dendrochronologia 20:217-231 